\title{
DUAS PALAVRAS E UM TESTEMUNHO
}

$\mathrm{Na}$ minha longínqua memória vou encontrar o Jobim como colega, primeiramente do Mestrado em Literatura Brasileira e, a seguir, do Doutorado em Teoria da Literatura, na Universidade Federal do Rio de Janeiro, onde eu já lecionava no Departamento de Ciência da Literatura, naquele período, um dos mais aguerridos do panorama literário e teórico do país. Entre os nossos professores, podemos citar Eduardo Portella, Afrânio Coutinho, Cleonice Berardinelli, Celso Cunha e Cyro dos Anjos, entre outros importantes mestres.

Formamos um grupo que nos levou à Biblioteca Nacional em um curso de Guilherme Figueiredo, para pesquisar sobre teatro. Prossegui aquele trabalho, que resultou no texto Censores de pincenê e gravata: dois momentos da censura teatral no Brasil, de 1981, dissertação de mestrado com a análise dos pareceres inéditos dos censores do Conservatório Dramático e a história da instituição (de 1830 a 1860), articulada como uma análise do discurso entre poder político-cultural e institucional, ideologia da censura e função dos intelectuais, depois publicada em nova estrutura. Em um capítulo do seu Formas da Teoria, de 2003, Jobim tratará do tema "Censura e Moral”, a partir dos pareceres de Machado de Assis, do Conservatório Dramático. Como não ver naquele estudo uma origem comum da nossa formaçãa? O trabalho de 2003 discute, ainda, outros temas importantes que vão de questóes culturais amplas, como o capítulo de abertura, dedicado a "Nacionalismo e Globalizaçáo", àqueles que tratam de aspectos teóricos ligados à narrativa e à história ou à intertextualidade. Um primeiro eixo de pesquisa que nos liga, portanto, refere-se à Literatura Brasileira, à Teoria da Literatura e aos temas culturais da identidade nacional brasileira.

Passados muitos anos, quando já professora em Roma, reencontro o Jobim como Diretor da Faculdade de Letras, da Universidade do Estado do Rio de Janeiro (UERJ), onde também lecionei. Desde entấo, temos colaborado em torno de pesquisas sobre Machado de Assis e Antônio Vieira, principalmente. A este núcleo deve-se ligar a sua colaboraçáo com o professor Silvano Peloso, da Universidade de Roma "La Sapienza". Da parceria institucional da Sapienza com a UERJ nasceram projetos importantes que culminaram no Congresso do Terceiro Centenário do nascimento do grande pregador jesuíta, comemorado em Roma, em 2008, e depois levado pelo mesmo grupo à Universidade de Lisboa e, finalmente, ao Rio de Janeiro, na UERJ, sob a coordenação de Jobim, Ana Lúcia de Oliveira e Antônio Celso 
Alves Pereira. Outro fruto da colaboração entre a Sapienza e a UERJ, com o patrocínio do ex-Reitor Antônio Celso Alves Pereira e do atual Reitor, Ricardo Vieiralves, foi a fundação da coleção Brasil-Itália da EdUERJ, sob a direção de Italo Moriconi, em que foram publicados volumes como Literatura e identidade e Descobrindo o Brasil, sob a coordenação de Jobim e Silvano Peloso, reunindo professores das duas instituiçôes universitárias citadas.

Em relação a Machado, não se pode esquecer o volume A biblioteca de Machado de Assis, organizado por Jobim, em 2001, importante volume coletivo para a consulta da bibliografia referente ao autor carioca, e o congresso de 2008, na UERJ, na comemoraçáo dos cem anos do desaparecimento do autor de Dom Casmurro. Na traduçáo do Quincas Borba, que organizei e orientei em 2009, na Itália (Viterbo, Sette Città), o posfácio é de Jobim, não só como justa homenagem à nossa parceria, mas também como reconhecimento pelos seus trabalhos na área. Um segundo eixo, assim, do perfil do Jobim configura-se pela sua capacidade de organizador da cultura que caracteriza as suas atividades institucionais de direção, coordenação e promoção.

Por último, náo poderia deixar de referir-me à literatura comparada que marcará também o seu trabalho de pesquisador, levando-o tanto aos aspectos teóricos da contemporaneidade, como ao trabalho crítico desenvolvido no seu estudo de 2012, A Crítica Literária e os Críticos Criadores no Brasil.

É importante lembrar que o professor José Luiz Jobim representa uma geração de estudiosos formados na Universidade brasileira, mas com especialização no exterior, capaz de construir pontes de intercâmbio que desprovincializam, sem subordinar o pensamento brasileiro.

Somo ao testemunho o valor da personalidade do homenageado de hoje, raro exemplo de ética acadêmica e de profissionalismo.

Sonia Netto Salomão (Sapienza, Universidade de Roma) 